UDK: 821.112.2(436).09-31 Келман Д. DOI: https://doi.org/10.18485/legado_hispanico.2020.ch14

\author{
Миодраг М. Вукчевић ${ }^{1}$ \\ Универзитет у Београду \\ Србија
}

\title{
ХУМБОЛТОВ СУСРЕТ СА АМАЗОНИЈОМ: МАГИЧНИ РЕАЛИЗАМ У КЕЛМАНОВОМ РОМАНУ МАПИРАҢЕ СВЕТА
}

\begin{abstract}
Резиме
Стварање оквира за сагледавање центалних идеја током одређеног периода у немачкој историји књижевности, након фазе изградње немачког националног корпуса и његове периодизације, суочава се данас са проблемом позиционирања према претходно изнетим гледиштима која су историјски имала тешке последице. Свако позивање на реалистичан приступ треба разумети у овом контексту. У роману Мапирање света (2005) Данијел Келман временом радње и ликовима представља историјски контекст значајан за формирање немачког идентитета, чије преиспитивање у знатно измењеним околностима и након стеченог искуства отвара питања 'реализма' у књижевним обликом понуђеним одговорима. Његово позивање на утицаје магичног реализма, које је примио преко латиноамеричке књижевности, изазвало је полемике у стручној јавности, не и покушај изналажења веза између обележја приписаним магичном реализму, с једне стране, и њихово тематизовање приповедним обликом с друге стране, односно њихово формирање у одређену жанровску врсту. Због тога, прилог истражује раскорак између Келманове мотивације и разлога за усмерење рецепције у одређен контекстуални оквир.
\end{abstract}

Кључне речи: историјски роман, магични реализам, наративни облик, Пруска.

\footnotetext{
${ }^{1}$ mvukcevic@fil.bg.ac.rs
} 


\section{1. Појава назива „магични реализам“ на немачком говорном подручју}

Потешкоће приликом дефинисања уметничког правца, његовог јасног разликовања од уметничког покрета попут надреализма или канонизованих књижевних раздобља, магични реализам у немачкој књижевности нема своје дефинисане оквире. Упркос томе, Маја Стефановић (2018: 219) указује на изненађујућу околност по којој није само ковање термина везано за говорно подручје немачког језика, већ се овде успоставила штавише теоријска основа за наведени правац, и то још пре него на латиноамеричком говорном подручју. Она наводи низ књижевнихтеоретичара према којимаје термин магични реализам (Magischer Realismus) први употребио немачки историчар уметности Франц Po (Franz Roh) 1923. године (2018: 220). Кључно је, међутим, што се облици уметничког правца према овој дефиницији стављају у узрочно-последичну везу са тада владајућим духом времена, времена у послератној Немачкој. С тога се повлачење песника у сопствени свет маште, унутрашњи, духовни свет тумачи као креирање стварности која се супротставља условима постојеће реалности. Из тог разлога, Стефановићева наิлазе немачких теоретичара у вези са деветнаестим веком чита као стварање традиционалног оквира из којег се дефинише реализам (2018: 222) док се иступање из датог оквира према чешком германисти Лудвика Вацлавека (Ludvík Václavek) представља као девијација човековог постојања у дехуманизованом друштву (1970: 144). Разлог за овакву врсту аргументације свакако је околност да се дела, која се могу сврстати у правац магичног реализма, појављују обично у кризним временима. Први примери овако обликованог наративног тока су дела Аустријанаца Густава Мајринка (роман Голем, $1915)$ и Франца Шпунда (роман Девахан, 1921) или пак Преображење (1915) Франца Кафке.

У периоду након 1945. године, тзв. „нулте тачке“ у немачком књижевном стваралаштву, Фолкер Ведекинг налази читав један низ имена (Алфред Андерш, Ханц Вернер Рихтер или Гинтер Ајх и Ернст Јингер) који се могу сврстати у правац магичног реализма. Према њему, ради се о писцима који су били у потрази за одговарајућим начином савладавања актуелне друштвено-политичке стварности „у нади за бољом Европом после рата и ратног заробљеништва, те разорених немачких градова“2 (Ведекинг 1971: 136). Маја

${ }^{2}$ «Krieg und Kriegsgefangenschaft, Zerstörung der deutschen Städte und Hoffnung auf ein besseres Europa [...]» (У тексту, сви преводи са страних језика су ауторски.) 
Стефановић томе додаје разматрања савремених теоретичара магичног реализма (Бауерс, Гинтер, Шанади, Ридс) који као представнике овог књижевног феномена на тлу немачког говорног подручја издвајају Гинтер Граса и његов двотомни роман Лимени добош (1959) или и писца Патрика Зискинда и роман Парфем из 1985. године (2018: 225). Наведеним делима насталим за време једног од поменутих периода савременог доба, могу се приписати дакле заједничка обележја, препозната као обележја магичниог реализма без обзира на период настанка.

\section{2. „Магични“ реализам у Келмановом роману Мапирање света}

Роман савремене немачке књижевности Мапирање света (2005), аутора Данијела Келмана, који је привукао значајну пажњу како у струци тако и у широј јавности, не мери се само његовим огромним успехом, већ и чињеницом да се бави темама које су за време објављивања романа, интегрисане у свеукупни друштвени контекст у којем је тада историјски релевантне догађаје требало адекватно обележити пред домаћом публиком. Још за време његовог настанка али и у време његовог појављивања, Келмановом роману, како се то чинило, звезде нису биле наклоњене. Али кормило судбине се окренуло у неочекивани успех. Шта је разлог томе? С аспекта књижевног рода није ништа неочекивано угледало дан. Међутим, прилком покушаја тематског омеђивања, категоризације на основу наративног облика или описа естетских облика, спотицање о овом или оном камену међашу је неизбежно. Према обележјима роман је могуће сврстати у више различитих конвеционалних типова, било историјски, авантуристички или путописни роман. У зависности од дефиниције, опет, и то у односу на предмет развоја тематизованог субјекта, могло би се говорити, штавише, о развојном односно образовном роману. Међутим, услов за контекст одређен на овај начин, је повезивање обележја, која се могу препознати као пруска, у корпус дефинисаног на концу као немачка национална обележја.

У полазишту, Данијел Келман је самом себи одредио такав оквир. Тако је и централни мотив насловне стране инспирисан актуелним квалификацијама књижевне критике. Ентузијазам овакве врсте може се пратити уназад све до расправе која је избила почетком деведесетихгодинаувези саредефинисањем књижевности након што се Немачка поново ујединила и што је постало видљиво у такозвано „немачко-немачком књижевном спору“. Али паралелно 
са тим, каже Херман, „водиле су се узавреле расправе о реализму“, (2013: 48) сконцентрисано на захтев изнесен према књижевности за њен ближи однос према стварности у контексту актуелног тренутка. Штавише, могло се чути за захтеве упућене књижевности, која, како се налазило, пише о томе да писање није више могуће, за укидање границе између књижевности и новинарства и окретање ка реалности, историјски датој, пре свега помоћу прецизног истраживања. Према томе, уместо одавања признања естетској вредности књижевности, тражи се реализам који књижевност одржава у животу (Билер 1998: 69). Све су гласније формулисани захтеви за „реализам доказа“ у оквиру фикције, „стварање чињеница реченицама“ (Вилемзен 1992: 191) и „релевантни реализам“ супротстављен доминацији сиве еминенције и „њиховом све већем незадовољству према животним записима млађе генерација која савременим начином живота затире сећања“ (Херман 2013: 48-49).

Праћењем наведене дебате у Немачкој се стиче утисак подвојености савремене културе. Традиционалне вредности у потпуној супротности су популарној култури садашњице. Реалиузам у смислу уже дефиниције, појмовно описујући стил реалистичног приказа, тешко се доводи у везуса популарним мотивима. Свет магије, чаробњаци, вампири и свемирске летелице познати из екранизација романа о Харију Потеру или трилогије Господара прстенова, те оживљавањем поново серијала познатог из 70-ихгодина, Ратазвезда, постали су саставни део света и одрастања деце. На трагу тржишних начела понуде и потражње, књижевност се прилагођава стварности помоћу особеном концепту постмодернистичке наративне фикције „засноване на стваралачкој синтези реалистичних и фантастичних елемената" (Нининг 2007: 416). Не заостаје Келманов роман Мапирање света ни у томе. Међутим, није било за очекивати да ће у поређењу са књишком верзијом, биоскопска 2012. доживети неуспех (Рајн 2013). Несразмерни успех повлачи за собом наравно питање разлога.

Одговор на питање за разлогом књижевног успеха се налази можда и у бројним текстовима из секундарне литературе. Према овој, предмет Келмановог романа Мапирање света се смешта или у контекст идеје о немачком духу, менталитету односно идентитету (Кинт 2012) насталом у 19. веку и у покушају разумевања перцепције властитог бића у иностраној литератури (Грабе 2014), или се пажња поклања историјском контексту времена у које је смештена радња романа (Олеско 2007). Али највеће интересовање науке изазивају пре 
свега главни ликови Карл Фридрих Гаус и Александар фон Хумболт (Витфилд \& Пајзер 2007, Хол и Кноблох 2012). Додуше, успеху допринео је такође хумористички приступ у роману, ироничним тоном пружајући сатиру на немачко схватање стварности (Катани 2008, Ете 2012, Верле 2015). За разлику од тога, интригантни елементи магичног реализма, дефинисаног као уметнички правац који фузијом реалне тј. опипљиве, видљиве, рационалне стварности с једне стране и магичне стварности у облику халуцинација и снова с друге стране ствара ону нама познату „трећу стварност“, осим у херменуитчкој кривуљи маште и идеологије (Шауман 2009: 447) и покушаја систематсог категорисања фантастичног приповедања у савременој књижевности (Херман 2013), нису детаљније истражени.

Славом овенчани роман Летеће лисище Марсела Бајера деценију раније (1995) доживео је у стручној јавноси рецепцију сличну Келмановом роману Мапирање света. Метафора великих љиљака из наслова Бајеровог романа на изворном језику, која се током радње појављјује на различитим местима, асоцира на разлику код ове врсте сисара којој, упркос томе што припада реду слепих мишева, недостаје ехолокација и има добро развијена чула вида и мириса. Тематизовањем начела запажања простора, у метатексту, радња смештена у време Другог светског рата се бави дакле митом о теорији завере помоћу контролисаних медија. Главни ликови Келмановог романа, Александар фон Хумболт и Карл Фридрих Гаус се баве такође начелима запажања простора. У складу са смислом за ред, толико својствен германском бићу услед, између осталог, пруског утицаја, начела реда се сматрају основом за запажање природе и облика у којој се појављује. Након неколико премера Гаус,

више неће залутати у пределу који познаје иначе боље од било кога другог, јер, све је он то фиксирао на карти. Некада, како му се то чинило, предео није само премерио, него измислио, као да је његовим радом постао стварност. Ништа што је неко некада премерио, је било или је могло бити као пре ${ }^{3}(268)$.

Доследно користећи глаголски облик конјунктива у свом роману, Келман ствара утисак хипотетичких односа иако говори

\footnotetext{
${ }^{3}$ [...] verirrte er sich nicht mehr, er kannte diese Gegend besser als irgend jemand sonst, schließlich hatte er all dies auf der Karte fixiert. Manchmal war ihm, als hätte er den Landstrich nicht bloß vermessen, sondern erfunden, als wäre er erst durch ihn Wirklichkeit geworden. [...] Nichts, was einmal jemand vermessen hatte, war noch oder konnte je sein wie zuvor.
} 
о историјски реалним личностима и стварним, конкретним резултатима њиховог рада. Глаголски облик који изражава могућност, претпоставку или жељу веома је тешко пренети у одговарајући облик на другом језику. Могућност потенцијала грађеног на српском језику аористом помоћног глагола 'бити' и радног глаголског придева захтева међутим промене у синтаксичкој структури што мења значење. Додуше, проблем није само граматичке природе, попут коришћења сложене или вишеструке негације, него иронични приступ постаје јаснији «que gracias a su infatigable ejercitación en el discurso indirecto nos ofrece un auténtico ejercicio del subjuntivo» ${ }^{4}$ (Ете 2012: 44). На тај начин немачки однос према свету, његовим мапирањем долази до изражаја у интеракцији науке и књижевности. Према Етеу, из тог односа могуће је тумачити његове резултате као «el resultado de una intensa canibalización de la ciencia: una pequeña biblioteca minuciosamente examinada en busca de elementos aprovechables desde el punto de vista narrativo» ${ }^{5}$ (2012: 44). Несумњиво, Келманови јунаци теже сазнању које црпе из стварности. Пример писма Фридриха Шилера упућеном свом пријатељу Кристијану Готфриду Кернеру (Ете 2012: 42-43), у којем критикује настојања Александра фон Хумболта, ставовима филозофији наклољеног класика приликом сагледавања стварности, указује на етичку димензију човековог односа према природи. И што се више и интензивније двојица научника баве мерењем света, то се све више и мере са њим. Келман у овој околности налази заправо питање мере, одмерености.

У релацији између науке и књижевности, издајањем сегмента мерљивости се разоткрива трагикомичан карактер одреднице 'култура'. У сцени током пловидбе чамцем на реци Рио Негро пратиоци Александра фон Хумболта, није само случај да домороци не причају приче, него њихова имена директно асоцирају на четири велика јужноамеричка писца (Zeyringer 2008: 43): Габријел (García Márquez), Хулио (Cortázar), Карлос (Fuentes) и Марио (Vargas Llosa), и моле да и он једном нешто исприча.

Не би знао ни за какву причу [...]. Али би могао да испева најлепшу немачку песму, у слободном преводу на Шпански. Изнад свих планинских врхова било је, беше тихо, у дрвећу без осетног ветра, а и

\footnotetext{
${ }^{4}[. .$.$] захваљујући неуморном вежбању у индиректном дискурсу, који нам нуди праву$ вежбу у субјунктиву.

5 [...] резултат интензивне канибализације науке: мала библиотека, која је пажљиво испитана на елементе који се могу користити с наративног гледишта.
} 
птице биле су, беху мирне, и ускоро биће, сви су мртви.

Сви га погледаше.

Готово, рече Хумболт. [...]

Опростите, рече Хулио. Није то могло бити све.

Наравно, не би то могло бити прича о крви, рату и преображењу, рече Хумболт, изиритиран ${ }^{6}(128)$.

Пародија на Гетеову песму Ноћна песма излетника (Wandrers Nachtlied, 1776/1780) интересантна је посматрано с два аспекта. C једне стране у контексту представљања немачке класике у страном окружењу и с друге стране мотива који су референцом на надчулно запажење уткани у роман. Као што је то познато, песнички преводи су суочени задатком преношења културног садржаја из једног мисаоног контекстаудруги.Дакле, разлика сеправи измеђумисаоних контекста. Али, како треба разумети изједначавање различитих мисаоних контекста преводом? Према томе, свако упрошћавање је покушај да се из оквира властитог схватања досегне до корена ствари. Уосталом, да ли би Келману помогао савет шпанског песника или његова помоћ приликом превода Гетеове песме на Шпански, не би ли се преведени текст, са извесним променама, превео поново на Немачки? Можда би такво поступање било стварно израз немачке прецизности.

Културну критику у случају погрешно изрецитоване песме Дирк Верле тумачи на за њега два могућа начина. Ако је усмерена против Гетеа, онда се ради о сатири, каже Верле, усмерене на погрешно схваћен културни империализам Немачке који је утемељен на вредностима Вајмарске класике (2015: 346). Против Хумболта усмерена, песма се критички представља као значајни културни производ без имало рефлексије, без исказаног разумевања естетског квалитета текста (Верле 2015: 347). Узимајући у обзир да Александар фон Хумболт, као поштовалац Гетеа, у џунгли цитира стихове Вајмарског песника, постаје јасно да се Келманов роман бави перцепцијом немачке класике у Латинској Америци, са ван немачких граница изнетим захтевима за хуманост и људском достојанству које, у другачијим културним условима и традицијама,

\footnotetext{
${ }^{6}$ Geschichten wisse er keine [...]. Aber er könne das schönste deutsche Gedicht vortragen, frei ins Spanische übersetzt. Oberhalb aller Bergspitzen sei es still, in den Bäumen kein Wind zu fühlen, auch die Vögel seien ruhig, und bald werde man tot sein./ Alle sahen ihn an./ Fertig, sagte Humboldt./ [...] Entschuldigung, sagte Julio. Das könne doch nicht alles gewesen sein./ Es sei natürlich keine Geschichte über Blut, Krieg und Verwandlungen, sagte Humboldt gereizt.
} 
треба преиспитати. Али ако се обрати пажња и на у роману садржане алузије на Гетеово учење о бојама, што би могло исто тако да се тумачи као коментар усмерен против Гетеа, и ако се овако конципирана аргументација стави у исту раван са образложењем за „представљање значајног културног производа без имало рефлексије, без исказаног разумевања естетског квалитета текста“" због Хумболтовог превода на Шпански (Верле 2015: 347), онда је и секундарна литература позвана на дубље рефлексије.

Проблем разграничења између стилских особености у дебати око садржаја романа односно приписивања обележја води ка разматрању жанра или типа романа. Књижевннни узор из историје немачке књижевности Келмановом роману чини, по много чему, роман Вилхелма Рабеа Сладокусац (Stopfkuchen) из 1890. године својим интертекстуалним референцама. Приповедач у роману из касног реализма стране стручне називе ставља у контекст домаћих појмова проистеклих из властите културне традиције, дефинисане кроз Хришћанско учење. На поступак слободног цитирања према Јевађељу по Матеји (6: 28) „»у пољу« (»Погледајте на љиљане« и тако даље) расту,“8 (Рабе 1983: 16) се наставља и даље усклађивање терминологије. Стављајући идеју о науци у контекст културног идентитета Рабе открива процес преображавања и не улепшава га, напротив. Укључене особе, попут главног лика Едуарда, морају се прилагодити овом открићу и реконструисати своје виђење света, што овај покушава у свом властитом процесу писања. Међутим, Рабе се на тај начин удаљава од Реализма.

\section{3. Келманов „преломљени реализам“}

Обојица, Хумболт и Гаус, деле жељу за емпиријском приступу свету, за мерењем и описом на основу прецизних података. Хумболт путује прво у Јужну, а потом у Северну Америку како би истражио и мерио њихове физичке површине. Дубоко укорењен у европском просветитељству, његов научни приступ је спутаван чим Хумболт са сапутником Бонпланом стиже у Јужну Америку и започиње сарадњу са тамошњим становниптвом. Програмски, Келман овај сегмент у свом роману назива «Weimarer Klassik goes Macondo» (Ленц 2007:

\footnotetext{
${ }^{7}[. .$.$] dass sie das Gedicht unreflektiert als hohes deutsches Kulturgut präsentiert, ohne$ dass sie ein Verständnis für die ästhetische Qualität des Texts aufbringt.

${ }^{8}$ »auf dem Felde« (»Sehet die Lilien« und so weiter) wächst,
} 
46) алудирајући на зачудни град назван Макондо који се у роману Сто година самоће налази у имагинарној земљи Пасквелија. Домороци стално причају разне приче, чак и када их свештеници због тога оштро кажњавају. Према Катарини Типелскирх (2009: 197) они заправо оживљавају и тако конкретизују наративну традицију Јужне Америке. Кехлман то исто ради за књижевност са његовог подручја, истражујући свет магичног реализма и северноамеричког постмодернизма из перспективе савременог немачког писца који тежи превазилажењу ограничења свог окружења, слично Хумболтовом поступању.

Келман је често критиковао естетска ограничења литературе у Немачкој између 1945. и 1989. године, констатује Фелиситас фон Лофенберг у разговору са писцем (2008: 34). Испоставља се да је управо то разлог за Келманово упуштање у књижевни експеримент, истражујући жанр историјског романа и приповедајући догађаје који су се догодили у време када је „мускетарија пуштена“ (Лофенберг 2008: 32), али уоквирено у текст који одражава естетику нашег времена. Келман и његови критичари већ су у више наврата дефинисали оно што постиже такозваним „преломљеним реализмом“ (gebrochener Realismus, fractured realism) и хвалили исти као „иновативну димензију његовог стила писања“ (Типелскирх 2009: 197)

Свој дериват „преломљеног реализма књижевног рода“ песник сврстава у ред дела латиноамеричких песника, предводника „магичног реализма“ (Келман 2007: 22). Окосницу дефиниције чини свакако поимовање реализма према немачкој књижевној традицији. у складу са тим, Михаел Шефел (2000: 526), такође, магични реализам карактеише као интегрисање тајне у приповеданом свету и преламање система реализма помоћу специфичних садржаја и формалних средстава. Као пример у Келмановом роману наводи алузије на митове новог света у којима непознати летећи објекти служе за објашњење овде присутне цивилизације. Уочавање непознатог летећег објекта за време пловидбе реком Ориноко, што није у потпуности незамисливо, стављено је у контекст потпуне исцрпљености путника и, услед тога, могућег привиђања:

Током дана, сати су се преливали једно у друго, сунце је висило ниско и горело над реком, болело је гледати у њега. [...] Пратила их је неко време метална плоча, летела је испред па иза њих, бешумно плутала небом, нестала, појавила се поново, на минут се толико приближила 
да је Хумболт закривљени одраз реке, њиховог чамца и самога себе на њеној светлуцавој површини дурбином препознао. Онда је великом брзином нестала и никада се није вратила ${ }^{9}(135)$.

Ипак, Келман идедаље и несумњиво тражи отклонодпарадигме реализма. Оно на шта његово приповедање алудира је друкчија традиција, она која е остала блискаусменом приповиједању: магични реализам Јужне Америке. Келман у својој збирци есеја Wo ist Carlos Montúfar? (2005) описује утицај који је Марио Варгас Љоса имао на њега. На основу тога Катарина Типелскирх поистовећује Келманову нарацију и „препуштајње староседелаца Јужне Америке својим причама, када примером личног живота конкретизују пут из дилеме која карактерише модерну западну књижевност." (2009: 202) Келман описује Александра фон Хумболта као човека искључиво европске врсте модерности, што значи да Хумболта занимају тачност, мерења и чињенице, али не и књижевно стварање, поезија и приповедање. Дакле, његова критика је јасно усмерена против идеализовања разума као тековине савременог доба. Из историјски и биографски тумачене лектире са Хумболтом као централном личношћу, Франк Хол (2012: 48) у њему препознаје персонификацију немачке идеје о погледу на свет (Weltbild), начелима функционисања односа у људском свету. Тим путем Хумболт, „укрштањем Дона Кихота и Хинденбурга [...] преувеличавањем, сужавањем и заоштравањем,“ (Келман 2005: 15) постаје представник света који себи присваја ексклузивно право на истину.

Контраст реалистичком поимовању Келман ствара митом обавијеним пределима, са ликовима који посећују људе током размене са митским светом. Пример митског односа према животу пеник даје сликом птица, која светлосним односима у простору симболизује нови живот. Хумболт запажа:

Понављаше се црте одраза птица над водом, чак и када је небо било празно.

Чудесни оптички феномен, рече Хумболт.

Нема то никакве везе са оптиком, рече Марио. Птице умираше непрестано, у сваком тренутку, уствари не чинише много тога другог.

\footnotetext{
${ }_{9}$ Tagsüber flossen die Stunden ineinander; die Sonne hing sehr tief und feurig über dem Fluß, es schmerzte, sie anzusehen. [...] Eine Zeitlang folgte ihnen eine metallene Scheibe, flog vor und dann wieder hinter ihnen, glitt lautlos durch den Himmel, verschwand, tauchte wieder auf, kam für Minuten so nahe, daß Humboldt mit dem Fernrohr die gekrümmte Spiegelung des Flusses, ihres Bootes und seiner selbst auf ihrer gleißenden Oberfläche wahrnehmen konnte. Dann raste sie davon und kam nie wieder.
} 
Њихови духови у одразима настављаше живот. Некуд мораше, на небу не хтедоше да их приме ${ }^{10}(110)$.

Више таквих примера, када се у окружењу познатом из митова појављују фигуре чија су својства такође присутна у митовима, Келману служе у функцији контра примера за поменуту идеју о дефинисању живота и света помоћу научног приступа Али тумачено у смислу схватања руковођеног рефлексијама о властитом бићу указује се на стереотипе изграђене кроз историју. Лек против овакве врсте егоцентизма јесте моменат који Кинт (2012: 370) назива „хумористичком рефлексијом на конструкције немачког бића у својим различитим облицима и потребама за преиспитивање. Роман се користи уходаним елементима схватања Немаца о себи и свега што је страно и огољује их у њиховој смешној појави.“11 Гаусов приступ свету приликом мерења предела гласи: „Пруски истраживач у овом моменту управо то чини међу митским бићима Новог света"12 (89).

Келманова посвећеност и најситнијим детаљима, која његовом роману даје чак одређену важност у актуелним историјским околностима, пројектује облике културног живота у просторне односе дискутабилних димензија. У скромној квалификацији Томаса Џеферсона о властитом положају, „постојања мале протестантске заједнице на крају света“13 (214), иронични или пак саркастрични дух северноамеричке идеје о себи се представља као реактивни процес настанка у одговору на суседе, католичку велесилу сједињених јужноамеричких држава. Док се у односу иземђу Хумболта и његовог пратиоца, француског колеге Бонплана, релативизују овакве и сличне крајности у тумачењима, сарадња са домороцима подиже степен апстракције на виши ступањ. Однос поверења је однос препознавања који ствара стварност: „Бонплан је њему био потребан.

\footnotetext{
${ }^{10}$ Immer wieder strichen Spiegelungen von Vögeln übers Wasser, selbst wenn der Himmel leer war./ Ein wundersames optisches Phänomen, sagte Humboldt./ Das habe nichts mit Optik zu tun, sagte Mario. Vögel stürben unablässig, in jedem Moment, eigentlich täten sie wenig anderes. Ihre Geister lebten in den Spiegelungen fort. Irgendwo müßten sie ja hin, im Himmel wolle man sie nicht.

11 [...] eine humoristische Reflexion über die Vielfalt und Fragwürdigkeit von Konstruktionen des Deutschseins. Der Roman nimmt sich etablierte Elemente des Selbstund Fremdverständnisses der Deutschen vor und macht sie in ihrer Lächerlichkeit durchschaubar.

${ }^{12}$ Ein preußischer Forscher tue genau das in diesem Moment unter den Fabelwesen der Neuen Welt.

${ }^{13}$ Man sei eine kleine Protestantengemeinde am Rand der Welt.
} 
Морао му је веровати“14 (Келман 2008: 135). Приликом заједничког рада са домороцима, оковања ногу које Хумболт не одобрава, отац Зеа указује на цивилизацијски јаз и на сагласност домородаца за улогу која им се приписује, услед чега се на крају појављује губитак поверења (Келман 2008: 113-114).

Међутим, аутор не полази од непосредног усвајања латиноамеричких метода приповедања. Јоахим Рикес у овој околности налази често погрешно схваћен однос Келмана према магичном реализму. Према њему, Келман нипишто не укључује појаву чудесног непосредно у стварност. Полазећи од тога „преломљени реализам“ дефинише као „неизвесност обележену у наговештајима“ (Рикес 2012: 87). Рикес своју тврдњу потпкрепљује примером Хумболтовог путовања за Јужну Америку када уочава митско биће, али то одмах релативизује као могућу халуцинацију:

Непосредно пре Тенерифе, видели су морско чудовиште. У даљини, готово прозирно испред хоризонта, тело змије се уздигло из воде, формирало два кружна завоја попут прстена и гледало их је, у телескопу врло јасно препознатљивим, очима светлуцавим попут драгог камења. Влакна танке браде висила су око уста. Само неколико секунди након што је поново уронило, сви су мислили да се ради о халуцинацији ${ }^{15}(45)$.

Према опису, Херман (2013: 61) тумачи могућност уочених стабала дрвећа која плутају водом, после чега је читаоцима прихватљива констатација приповедача, по којој сви верују да се ради о привиђењу. Његову аргументацију потврђује јаче израженом хипотезом приликом коришћења глаголског облика конјунктива II уместо блажег облика конјунктива I којим се од приповедача открива веровање путника, а они прихватају да су подлегли грешци.

\section{4. Историјски роман}

Посвећеност детаљима, која елементима приповедног облика наговештава значење које надилази саму приповедану радњу, од

\footnotetext{
${ }^{14}$ Er brauchte Bonpland. Er mußte ihm vertrauen.

${ }^{15}$ Kurz vor Teneriffa sichteten sie ein Seeungeheuer. In der Ferne, fast durchsichtig vor dem Horizont, hob sich ein Schlangenleib aus dem Wasser, bildete zwei ringförmige Verschlingungen und blickte mit dem Fernrohr sehr deutlich erkennbaren Dedelsteinaugen zu ihnen herüber. Um sein Maul hingen barthaardünne Fasern. Schon Sekunden nachdem es wieder untergetaucht war, glaubte jeder, er hätte es sich eingebildet.
} 
посебног је значаја за Келманов текст. У сцени искрцавања на острво описују се, између осталог, товар који научници на чамцу носе са собом. Део пртљага чине алати за истраживање састављени од кутија, лешева и кавеза за животиње. Кутије садрже много осушених биљака, као и Хумболтове дневнике и његове инструменте за мерење. Алузијом на друштвено стање после завршетка Другог светког рата, алегоријско тумачење скупа ових предмета могуће je, наиме, повезати са основним ставом у немачкој књижевности наведеног времена и њену заокупљеност тачно утврђеним и стравно доказивим чињеницама. Симптоматична је слика мајмуна и папагаја, отргнутих из света у којем су живели и сада затворених у кавезу. Њихова појава симболизује егзотичне локације и теме у књижевности оног времена, која нису довољно обрађена нити интегрисана у истрорији немачке књижевности. Приликом боравка на острву за папагаје се каже: „Један је сморено зурио у празно, други непрестано мрмљао жалопојке на лошем Шпанском. ${ }^{“ 16}(140)$ Такође, на крају овог поглавља Хумболт и Бонплан током невремена седе на обали острва у реци Ориноко. Тада примећују отпад који плута реком: „Убрзо нису знали колико дуго чекају. Једном приликом вода је носила мртву краву, потом поклопац клавира, потом шаховску таблу и поломљену столицу за љуљање."17 (141 и сл.) Као што је то често случај у роману, приповедана ситуација буди сумњу:

Хумболт је пажљиво извадио сат, ослушкивао његово тихо Париско куцање и вирио кроз мушему тражећи казаљке. Или је невреме почело пре неколико минута или су већ дванаест сати били заглављени, или је киша не само реку, шуму и небо него и временски ток пореметила, неколико часова буично однела са собом, па се ново подне са вечерњим часом и следећим јутром слило у једно ${ }^{18}(142)$.

\footnotetext{
${ }^{16}$ Der eine glotzte bedrückt vor sich hin, der andere murmelte unablässig Beschwerden in schlechtem Spanisch.

17 Bald wußten sie nicht mehr, wie lange sie warteten. Einmal war eine tote Kuh vorbeigetrieben, dann der Deckel eines Klavieres, dann ein Schachbrett und ein zerbrochener Schaukelstuhl.

${ }^{18}$ Humboldt holte vorsichtig die Uhr hervor, horchte auf ihr leises Pariser Ticken und spähte durch die Wachstuchhülle nach den Zeigern. Entweder war der Beginn des Gewitters erst wenige Minuten her, oder sie saßen schon über zwölf Stunden fest, oder aber der Regen hatte nicht bloß Fluß, Wald und Himmel, sondern die Zeit selbst durcheinandergebracht, hatte ein paar Stunden einfach fortgespült, so daß der neue Mittag mit der Nachtstunde und dem nächsten Morgen zusammenfloß.
} 
Испреплитање временских токова као елеменат приписан приповедном правцу, дефинише, несумњиво, стилско обележје романа. Дело се квалификује дакле естетски. Међутим, Хумболт и његов однос према свом пратиоцу Бонплану с једне стране и Гаусов однос према сину из другог брака, Евгенија, с друге стране, су референтне везе за јунаке романа, којима додуше јасно исказују свој карактер, али се улогом описаних веза у њиховом животу манифестује додатно симболична вредност. Протагонисти преузимају дискурзивну функцију историјске рефлексије о пруском мезанину према схватању о немачком идентитету као свом националном. У Хумболтовом случају се појављује немачкофранцуски однос, иначе, обележен историјским тензијама, док се у Гаусовом случају распознаје однос Немачке према Сједињеним Америчким Државама. И у контексту значења датог у наслову романа Мапирање света, свет изворне културе јунака се шири према почетку истраживачког грађења новог света. Планински врхови и димни знак, географска мапа и тродимензионални линијски графикон са омота, симболизују начела организованог реда која чине просторну перцепцију, препознавање природе и њених облика у просторној димензији.

Рационални приступ немачког менталитета, разумевања споственог бића склоног реалистичном сагледавању стварности кроз емпиријски доказиве вредности, Келман пародира у историјском контексту. Управо у ту сврху користи контра пример научном приступу дефинисања живота и света, пре свега мистичномагични елеменат. Пошто се у пасажама са научним дискурсом од тога иначе тематски и мотивима дистанцира, Келман временским концепцијама буди идеје о цикличном схватању времена али их, неочекивано, Хумболтовом дефиницијом животног циклуса ставља у контекст хришћанске митологије: „У свакој шаци земље беше некада један човек и пре тога други човек“19 (123). Исто као што потешкоће у прилагођавању простору захтевају време, оне тако указују и на разлике у схватању времена, што је на пример случај са цикличним схватањем времена: „Човек је, написа, тек на почетку. Приметио је да је реченица два пута исписана и избриса је. Човек је тек на почетку! Трепнуо је и избрисао реченицу по други пут“20 (165).

\footnotetext{
${ }^{19}$ Jede Handvoll Erde sei einmal ein Mensch gewesen und vorher ein anderer Mensch [...]. ${ }^{20}$ Man sei, schrieb er, ja erst am Anfang. Er bemerkte, daß der Satz jetzt zweimal dastand, und strich ihn aus. Man sei ja erst am Anfang! Er blinzelte und strich ihn zum zweitenmal.
} 
Тренутак када приликом писања Хумболт примећује да је реченицу написао два пута, не примећујући поновљање радње пре њеног извођења, и понављање опет исте ситуације налик на реализовање ситуације већ виђеног, подразумева пројекцију могућих светова, снова и илузорних стварности у реалном животу.

Ситуација сличних околности описује Бонпланов доживљај у сну, када се јављају осећања њему позната из јаве, познато осећање сигурности боравка у Паризу, пре буђења у јутро када крећу ка врху планине Кимбораца. У овом контексту треба напоменути констатацију Маје Стефановић и Мартине Лучић, које из тумачења Луиса Леала о магичном реализму закључују да „магични реализам као постмодернистички концепт проширује конвенције традиционалног реализма који језаснован на емпиријским доказима, не укључујући могућност различитих перцепција стварног.“ (2018: 539). Антитетично пројектована осећања заштићености и неизвесности у контексту осећаја за време стичу алегоријско значење. Оно се препознаје у унутрашњем наративу. Наиме, ако се за протагонисте претпостави дискурсивна функција историјске рефлексије према којој однос Бонплана и Хумболта осликава француско-немачке односе, онда је сасвим могуће тумачење дела у актуелним односима. Уобличено како поредбеном алегоријом у историјски роман тако и у немачки образовни роман са његових три периода, дело приказује историсјки ток према подељеној Немачкој, потом преко уједињене у новом почетку, те коначно њен улазак у поменуто истраживачко грађење света.

Попут Бонпланове бојазни која баца сенку над његову одлучност, изградња новог света, његово мапирање, такође, представља нови почетак пренето метонимијом природе која сама себе регулише: „По ведром времену стигли су до краја канала. [...] Сада тек, рекао је, постојао је канал, заиста“21 (135-136), констатује Хумболт. Шетњу немачке историје канапом могуће је тумачити исто тако у подвојеној појави немачке културе, чији највећи симбол, Гете као универзални научник, својим бављењем природним наукама, између осталог учењем о бојама, сједињује у себи у оба лица. У том погледу, неочекиваном успеху романа допринела је коначно и искрена рефлексија о властитом бићу и њена „пародија у контексту“ (Верле 2015: 347), која разоткрива неочекивано схватање хумора. Гаусово питање „да ли се ради о магарцу који је узео себи за право

\footnotetext{
${ }^{21}$ Bei klarem Wetter erreichten sie das Ende des Kanals. [...] Jetzt erst, sagte er, existierte
} der Kanal wirklich. 
да коригује Њутонову теорију светла“22 (158), мислећи на Гетеа, уистину се откривају до сада не запажене карактеристике.

У овом смислу, немачки однос према реализму у разматрању Корнелија Кваса стиче ново значење за разумевање магичног реализмакао врсте реалистичног наратива. Наиме, акосеразумевању сврхе реалистичког наратива у „репродукцији стварности“ која почива на „копирању стварности која је изван дела“ (Квас 2016: $15)$ дода друго значење реализма (сазнавање стварности), према наводима Стефановићеве и Лучићеве, које сврху наративног облика магичног реализма налазе у „проширивању (трансгресији) појмова стварности и истинитости" (2018: 537) аутопародија на немачки менталитет, такође, шири границе разумевања људског сагледавања животног окружења. Читано као историјски роман са примесама магијског реализма, Келманово дело смештањем фиктивних елемената у релаистичан оквир сведочи, према томе, о историсјком искуству и његовим перспективама. Недостатак анализа и тумачења у секундарној литератури на наведени контекст, могуће је објаснити из традиционалне привржености основним дефиницијама и њихово фаворизовање у односу на неизвесност иновираних облика. Јер, оно што ови крију изискује прихватање измењене стварности. Реч је о промени парадигме коју Квас, у ослањању на Аристотелове дефиниције термина нужности и вероватности, одређује пресласком са перцепције уметничког дела као „реплике живота“ на његово разумевање као „животне истине“ (2016: 15).

Из потребе суочавања с прошлошћу пример немачкофранцуског односа, стављен у историјски референтни оквир, указује дакле на ограничења немачког самопоштовања. Сви описани поступци очигледно имају за циљ преиспитивања Хуболтовог рационализма и то тако што ће се они елементи накнадно поставити као релано постојећи, којима Хумболт најпре нема приступ. У намери да се докаже као различит, образац који служи за контраст Хумболтовом систему стварности, је песништво. Бонплан редовно посеже за иронијом да би Хуболту указао на његово ограничено схватање. На Хуболтово објашњење да је успоном на Кимборацо вулканизам сахрањен, Бонплан реагује са: „Штета, уствари [...]. Поседоваше поезију“23 (209). Дакле, услови за реално сагледавање стварности у садашњости су ограничени. Исто важи за обим

\footnotetext{
${ }^{22}$ [...] ob das der Esel sei, der sich anmaße, Newtons Theorie des Lichts zu korrigieren. ${ }^{23}$ Ein Jammer eigentlich [...]. Er habe Poesie gehabt.
} 
рецепције књижевног дела, који не јамчи за довољно широк спектар постављених питања. Из тога се намеће закључак о магичном односу релевантности као константе и протока времена као варијабле који у резултату успостављају функцију дефинисања релативне или пак потребне дистанце.

\section{БИБЛИОГРАФИЈА}

Бajep 2010: Marsel Bajer. Leteće lisice. Preveo s nemačkog Jan Krasni, Beograd: Geopoetika.

Билер 1998: Maxim Biller. «Soviel Sinnlichkeit wie der Stadtplan von Kiel. Warum die neue deutsche Literatur nicht so nötig hat wie den Realismus. Ein Grundsatzprogramm» (први пут објављено y: Die Weltwoche 30, 25.07.1991). Maulhelden und Königskinder. Zur Debatte über die deutschsprachige Gegenwartsliteratur. Andrea Köhler u. Reinhard Mohr (eds.). Leipzig: Reclam, 62-71.

Вацлавек 1970: Ludvík Václavek: «Der deutsche magische Roman». Philologica Pragensia, 8: 144-156.

Ведекинг 1971: Volker Christian Wehdeking. Der Nullpunkt. über die Konstituierung der deutschen Nachkriegsliteratur (1945-1948) in den amerikanischen Kriegsgefangenenlagern. Stuttgart: J. B. Metzlersche Verlagsbuchhandlung.

Верле 2015: Dirk Werle. «Unvollständiges Verstehen' am Beispiel einer Goethe-Parodie in Daniel Kehlmanns Roman Die Vermessung der Welt. Ein Beitrag zur Erforschung interpretatorischer Praxis». Andrea Albrecht et al. (ed.), Theorien, Methoden und Praktiken des Interpretierens. Berlin / Boston: de Gruyter, 345-365.

Вилемзен 1992: Roger Willemsen. «Fahrtwind beim Umblättern. Roger Willemsen über den Streit der jungen deutschen Literaten». Der Spiegel, 46: 190-191.

Витфилд 2007: John Whitfield: «Opposites attract». Nature, 445/15: 713-714.

Грабе 2014: Katharina Grabbe. Deutschland - Image und Imaginäres. Zur

Dynamik der nationalen Identifizierung nach 1990. Berlin / Boston: de Gruyter.

Ете 2012: Ottmar Ette. «De cómicos e histéricos. Una réplica a la sátira sobre eruditos de Daniel Kehlmann». Revista Internacional de Estudios Humboldtianos HiN, XIII/25: 41-45. 
Катани 2008: Stephanie Catani. «Formen und Funktionen des Witzes, der Satire und der Ironie in der Vermessung der Welt». Gunther Nickel (ed.). Daniel Kehlmanns Die Vermessung der Welt. Materialien, Dokumente, Interpretationen. Reinbek: Rowohlt, 198-215.

Квас 2016: Корнелије Квас. Границе реализма. Београд: Завод за уџбенике, 2016.

Келман 2005: Daniel Kehlmann. «Wo ist Carlos Montúfar?». Wo ist Carlos Montúfar? Über Bücher. Reinbek: Rowohlt, 9-27.

Келман 2007: Daniel Kehlmann. Diese sehr ernsten Scherze. Poetikvorlesungen. Göttingen: Wallenstein.

Келман 2008: Daniel Kehlmann: Die Vermessung der Welt. Reinbek: Rowohlt.

Кинт 2012: Tom Kindt. «Die Vermessung der Deutschen. Zur Reflexion deutscher Identität in Romanen GeorgKleins, Daniel Kehlmanns und Uwe Tellkamps». Zeitschrift für Germanistik, 22/2: 362-373.

Ленц 2007: Michael Lentz. «Die Fremdheit ist ungeheuer. Gespräch über historische Stoffe in der Gegenwartsliteratur». Neue Rundschau 118/1: 33-47.

Лофенберг 2008: Felicitas von Lovenberg. «Ichwollte schreiben wie ein verrückt gewordener Historiker' Ein Gespräch mit Daniel Kehlmann in der Frankfurter Allgemeinen Zeitung, 9. Februar 2006». Gunther Nickel (ed.). Daniel Kehlmanns Die Vermessung der Welt. Materialien, Dokumente, Interpretationen. Reinbek: Rowohlt, 26-35.

Нининг 2007: Ansgar Nünning. Metzler Lexikon Literatur-und Kulturtheorie. Stuttgart: Metzler.

Олеско 2007: Kathryn M. Olesko. «The World We Have Lost History as Art». Isis, 98/4: 760-768.

Пајзер 2010: John Pizer. «Skewering the Enlightenment: Alexander von Humboldt and Immanuel Kant as fictional characters». Atlantic Studies, 7/2: 127-142.

Рабе 1983: Wilhelm Raabe. Stopfkuchen. Eine See- und Mordgeschichte. Stuttgart: Reclam.

Рајн 2013: Jan Rhein. Die Bilder wollen automatisch anders geschnitten werden. Die Verfilmung von Daniel Kehlmanns Die Vermessung der Welt. Lille: Université Charles-de-Gaulle Lille-III.

Рикес 2012: Joachim Rickes: Daniel Kehlmann und die lateinamerikanische Literatur. Würzburg: Königshausen \& Neumann.

Стефановић 2018: Маја Стефановић. «Магични реализам у немачкој теоријској мисли». Иван Јовановић (ур.), Наука и 
савремени универзитет 7. Језици и књижевности у контакту и дисконтакту. Књ. 1. Ниш: Издавачки центар Филозофског факултета Универзитета у Нишу, 219-230.

Стефановић \& Лучић 2018: Маја Стефановић \& Мартина Лучић. «Границе реалног и фантастичног: Магични реализам као врста реалистичног наратива». Philologia Mediana, 10: 535-546. Типелскирх 2009: Karina von Tippelskirch. «Paradigms and Poetics in Daniel Kehlmann's Measuring the World». Symposium: A Quarterly Journal in Modern Literatures, 63/3: 194-206.

Херман 2013: Leonhard Herrmann. "Andere Welten - fragliche Welten. Fantastisches Erzählen in der Gegenwartsliteratur». Silke Horstkotte (ed.), Poetiken der Gegenwart. Deutschsprachige Romane nach 2000. Berlin / Boston: De Gruyter, 47-65.

Цајрингер 2008: Klaus Zeyringer. «Gewinnen wird die Erzählkunst: Ansätze und Anfänge von Daniel Kehlmann's 'Gebrochenem Realismus.'» text+kritik, 177: 36-44.

Шауман 2009: Caroline Schaumann. «Who Measures the World? Alexander von Humboldt's Chimborazo Climb in the Literary Imagination». German Quarterly, 82/4: 447-468.

Шефел 2000: Michael Scheffel. «Magischer Realismus». Fricke, Harald und Georg Braungart Reallexikon der deutschen Literaturwissenschaft, Bd. 2: H-O. Berlin / New York: de Gruyter, 526-527. 


\title{
HUMBOLDT MEETS THE AMAZON: THE MAGICAL REALISM IN KEHLMANN'S NOVEL MEASURING THE WORLD
}

\begin{abstract}
Summary
The creation of a framework in order to get an overview of the central issues of a certain time in German literary history, after the phase of building the German National Corps and its periodization, today faces the problem of taking a position against previously stated views that have historically had grave consequences. Any reference to a realistic approach should be understood in this context. In the novel Measuring the World (2005), Daniel Kehlmann, with the time of the story told and the characters, the historical context presented is important for the formation of German identity, whose re-examination in the changed circumstances and after gained experience, raises the questions of 'realism' by the answers offered in the literary form. His reference to the influences of magical realism, which he received, as he states, through Latin American literature, has caused controversies in the professional public, but no attempt was made to find links between attributes of the magical realism on the one hand, and how they are thematized by the narrative form on the other, respectively their formation into a specific genre type. Therefore, the paper explores the discrepancy between Kehlmann's motivation and the reasons for the reception being directed to a particular contextual framework.
\end{abstract}

Keywords: Historical fiction, magic realism, narrative form, Prussia. 